\title{
Fashion Vocabulary: Borrowing, Adapting and Rethinking
}

\author{
Ekaterina M. Nedopekina \\ Peoples' Friendship University of Russia (RUDN University), \\ 6, Miklukho-Maklaya str., Moscow, Russian Federation, 117198 \\ Corresponding author: nedopekina_em@rudn.ru
}

\begin{abstract}
Fashion is a rather significant mechanism that organizes the life of any society and regulates the social behavior of people. It subordinates not only the choice of clothing, interior, personal hygiene items, gastronomic tastes, musical preferences, but also the way of thinking, the formation of criteria for assessing the phenomena of reality. At the same time, fashion is not only a powerful social regulator, but also a significant cultural phenomenon, the study of which is of particular importance nowadays. In this context, the vocabulary of fashion is interesting, as, on the one hand, it enriches the Russian language due to the abundant borrowing of foreign words, on the other hand, it indicates how actively the Russian language adapts new names for fashion items, and demonstrates how Russian mentality and culture accept this vocabulary. In order to consider the Russian vocabulary in the sphere of "fashion" in all three aspects, it is important to trace the derivation of the lexical meaning of the denotations of the "fashion" semantic field in their connection with the historical period and the change in the native speakers' way of thinking in different historical times of the country. To this end, it is necessary to turn to the etymology of the basic elements of the Russian wardrobe, identify their coherence with the gender of their owners and trace how this coherence has been changing over time, as well as analyze the ways of grammatical adaptation of borrowed vocabulary in the Russian language, and finally, note the functional specifics of the same lexemes in Russian and other donor languages.
\end{abstract} derivation

Key words: fashion, clothing, vocabulary, borrowing, adaptation, assimilation, grammar,

\section{Acknowledgment:}

The author is grateful to A.M. Sofiyskaya for help in collecting research material.

\section{Article history:}

Received: 30.07 .2020

Accepted: 01.12.2020

\section{For citation:}

Nedopekina, E.M. (2021). Fashion Vocabulary: Borrowing, Adapting and Rethinking. RUDN Journal of Language Studies, Semiotics and Semantics, 12(1), 105-120. doi: 10.22363/2313-22992021-12-1-105-120

(C) Недопекина Е.M., 2021

This work is licensed under a Creative Commons Attribution 4.0 International License https://creativecommons.org/licenses/by/4.0/ 


\title{
Лексика сферы моды: заимствование, адаптация и переосмысление
}

\author{
Е.М. Недопекина \\ Российский университет дружбы народов, \\ 117198, Российская Федерация, Москва, ул. Миклухо-Маклая, 6 \\ nedopekina_em@rudn.ru
}

\begin{abstract}
Аннотация. Мода - довольно значимый механизм, организующий жизнь общества и регулирующий поведение людей в нем. Она подчиняет своему влиянию не только выбор одежды, интерьера, предметов личной гигиены, гастрономические, музыкальные предпочтения, но и образ мысли, формирование критериев оценки явлений действительности. При этом мода не только мощный социальный регулятор, но и значимый культурный феномен, изучение которого в наши дни приобретает особую важность. В этом контексте интересна лексика моды, которая, с одной стороны, обогащает русский язык за счет обильного заимствования иностранных слов, с другой стороны, свидетельствует о том, как активно русский язык адаптирует новые названия предметов моды, и с третьей стороны, демонстрирует, каким образом русская ментальность и культура принимают эту лексику. Для того, чтобы рассмотреть русскую лексику сферы «мода» во всех трех аспектах, важно проследить деривацию лексического значения денотатов семантического поля «мода» в их связи с исторической эпохой и изменением мышления носителей языка в разные исторические периоды жизни страны. С этой целью необходимо обратиться к этимологии базовых элементов русского гардероба, выявить их связь с гендерной принадлежностью их обладателя и проследить как эта связь меняется со временем, а также проанализировать способы грамматической адаптации заимствованной лексики в русском языке, наконец, отметить функциональную специфику одних и тех же лексем в русском языке и языке-доноре.
\end{abstract}

Ключевые слова: мода, одежда, лексика, заимствование, адаптация, ассимиляция, грамматика, деривация

\section{Финансирование. Благодарности.}

Автор выражает благодарность А.М. Софийской за помощь в сборе материала исследования.

\section{История статьи:}

Дата поступления: 30.07.2020

Дата приема в печать: 01.12.2020

\section{Для цитирования:}

Недопекина Е.M. Лексика сферы моды: заимствование, адаптация и переосмысление // Вестник Российского университета дружбы народов. Серия: Теория языка. Семиотика. Семантика. 2021. Т. 12. № 1. С. 105-120. doi: 10.22363/2313-2299-2021-12-1-105-120

\section{Introduction}

The use of borrowings in the semantic field «fashion» is dictated by the need to name clothing items which appeared as a result of the import of a huge number of different goods in the Peter and Catherinian eras, when the names of the basic wardrobe were excepted by the Russian language. A similar linguistic situation 
developed after the collapse of the Soviet Union, when a stream of information, new cultural phenomena, household items, including wardrobe items that required naming in Russian, poured into Russia from the West. The vocabulary of a foreign fashion discourse, interacting with proper Russian names, represents a significant layer of words, which today is characterized by widespread use among Russian native speakers and great internal dynamism. The chronological sequence of the penetration of borrowings in the field of fashion into the Russian language is due to gradual expansion of Russia's ties with different countries and their nations. At all historical stages, the adaptation of foreign vocabulary took place under the influence of two processes: on the one hand, overcoming the conservatism of the linguistic structure, which seeks to create terms with common Slavic roots (purity of the language), on the other hand, the mobility of the national vocabulary, its flexibility (living nature of the language). It is also important that the very nature of borrowings dictates the need for their translation, carried out in the process of transferring a word to a foreign language environment, its certain cultural adaptation $[1 ; 2]$. This determines the specificity of the «fashion» terms in the space of the Russian-language linguistic culture.

This study shows how deeply borrowed «fashion» terms penetrated into the Russian language, how firmly these words have become established in our everyday speech. The widespread use of borrowings in such a linguistic area as «fashion» concerns everyday life and serves as a reflection not only of the dialogue of unrelated cultures, but also as a means of intercultural communication. However, despite the powerful influx of borrowings, which can lead to the «erosion» of the Russian word, language as a self-developing mechanism is able to get rid of unnecessary things.

\section{Wardrobe Item Names and their Gender}

As a matter of priority, it is necessary to highlight common words such as pубаха [rubakha] 'shirt', derived from the common Slavic *robs - pyб — «clothes made of coarse fabric», Serbo-Croatian $p y \sigma$ — «seam», Latvian rùobs — «notch», German Rant Rant — «edge, hem». Pубаха 'shirt' literally means «hemmed clothes (with a border)» [3. P. 346]. The modern meaning of рубаха (рубашка [rubashka] after a change in the period of the second palatalization) has some shades of the previous meaning: «an item made of dense fabric for the upper body». According to the explanatary dictionary by D.N. Ushakov, рубашка's one of the meanings is «clothing made of lightweight fabric for the upper body, used as both underwear and outwear» [4. P. 604]. This definition clarifies the original meaning of the borrowing «рубашка» as underwear, which expands the original interpretation, but corresponds to it, since the way of wearing the item is the same; and as a garment to be worn on the upper body, which also still corresponds to and refines the original understanding. However, S.I. Ozhegov notes that the polysemy of this word makes it possible to distinguish meanings by gender. Thus, S.I. Ozhegov asserts that a shirt 
as underwear is an attribute of only a woman's wardrobe, while a shirt as an outwear is a man's outfit [5. P. 674].

It is worth noting that such distinctions have come into use relatively recently, and, as the British sociologist J. Entwistle believes, «clothing is one of the most accurate and profitable examples, with the help of which it is possible to show and explain how the body is connected with the gender and what makes it feminine or masculine. Therefore, any discussion about the phenomenon of fashion should concern the question of what means fashion uses to state the difference between the two sexes, male and female, and how it provides clothes/body with the connotations of masculinity and femininity» [6. P. 146]. Thus, gender codes inscribed in garments act not only at the object-conceptual level, but also at the abstractlinguistic level.

In view of the presence of this phenomenon, it is worth considering other names, for example, кофта [kofta] 'sweater jacket'. Since there are references to the Swedish lexeme kofta, Danish kofte - «short dress or raincoat», Norwegian kufta — «wide clothing, travel raincoat», kufte — «women's sweater jacket», this word cannot be considered as Russian and it follows that it has western origin. The source of the Slavic and Scandinavian words, perhaps, is the Lower German Bremen variant kuft — «coarse wool caftan», Baltic-German kuft — «home jacket, pajamas». Some researchers attempted to establish the connection of these words with the Turkic kaftan [7. P. 355]. Others suggest (which is less likely) a connection with the Persian-Turkish kufter — «fabric» [8. P. 537]. However, despite the differences in opinions of the etymology of this name, in all cases there is a tendency to change its lexical meaning in Russian environment. As a result, regardless of the actual way of the term's penetration into the language, there is a differentiation from the name of a specific element of women's clothing with a certain style, fabric, and purpose to the modern generalized gender-neutral name of any short upper part of clothing included in the thesaurus only of the colloquial and everyday functional style. So, the explanatory dictionary by T.F. Efremova gives the following definition: «1. Short — usually waist-length or hip-length women's clothing. 2. outdated. Women's home clothes, worn over a shirt at night. 3. Short loose men's clothing made of soft fabric. <...>» [9. P. 436].

Пиджак [pidzhak] 'jacket' is another example of a diachronic change in the gender focus of a wardrobe item. The name is borrowed from the English language, where pea-jacket - «jacket, short coat» from the Middle Dutch pie - «biker jacket» (hence the dialect/colloquial «спинжак» [spinzhak] — «the one that covers the back») — was used to refer to outwear of each sex. The modern meaning is «the upper part of a classic suit», in the official sense-male only; the female version of a similar product is called жакет [zhaket] 'ladies' jacket'. On websites that sell garments or publish materials on the topic of wearing a costume, in catalogues, books devoted to fashion poetics, these elements have a strictly indicated context of use. Suffice it to mention the colloquial mnemonic rule «Jack wears a jacket, 
Caddis wears a jacket for ladies», which simplifies memorizing the use of these names even at the everyday level.

Other elements with a high degree of assimilation, such as, for example, блузка [bluzka] 'blouse', being originally a male wardrobe item, gradually change gender focus. «Блуза» [bluza] 'blouse' was borrowed in the first third of the 19th century from French, in which blouse comes from Middle Latin pelusia — «Pelusian (clothing)» (from the name of the Egyptian city Pelusium). At first, the word meant men's clothing [10. II. P. 145]. In the 1900-1910s, blouses were considered a part of lingerie, because they had very complex decorations in the form of embroidery or lacing, and these very elements were characteristic of underwear. Therefore, for a long time, this element as a part of a daily outfit was considered exclusively masculine. Explanatory dictionaries in the late 20th century define a blouse as a lexeme with the meaning «outwear made of thin fabric in the form of a short fitted shirt, a women's light jacket» [9. P. 193]. The men's version of the blouse received the nomination «рубашка» 'shirt' regardless of the presence of patterns and decorations on it. The same is observed in the lexical meaning of the word туника [tunika] 'tunic'. Etymologically, туника 'tunic' (coll. «исподнее» 'underwear') is «a shirt (mainly for men) in the form of a bag without shoulder seams, which was worn under outwear» [11. P. 463]. The actual meaning implies a different meaning - «mainly a short dress or an elongated sweater jacket worn by women» [5. P. 812]. A special kind of a sweater jacket is «толстовка» [tolstovka] 'sweatshirt' (from the name of the Russian writer Leo Tolstoy) - a term introduced to imitate the style in the writer's clothes, means «a wide long men's blouse, pleated and with a belt». Currently it is an attribute of both male and female wardrobe.

«Костюм» [kostyum] until the 18th century, костюм [kostyum] 'suit' had the following interpretation: «constantly worn clothes, the usual daily combination of its parts», also 1. «A set of men's clothing, consisting of trousers, a jacket, a shirt, a tie». 2. «Fancy, carnival ensemble. Theatrical costume» [12. P. 779]. Later, the dictionary by D.N. Ushakov introduces two meanings, one of which has a clear indication to «femininity»: 1. «A complete set of men's dress. Lounge suit». 2. «Women's outer dress, consisting of a jacket and a skirt» [4. P. 248]. This confirms the theory of manipulation of fashion by gender boundaries.

A similar process is observed in the change in the lexical meaning of the word «брюки» [bryuki] 'trousers' borrowed from the Old French broc — «clothes for the legs and body». The modern interpretation suggests the following: «the lower part of the classic costume» [4. P. 46]. From the point of view of psycholinguistics, the term «брюки» 'trousers' is more often used to nominate classic styles; for other varieties of this garment the onym «штаны» 'pants' is used.

This distinction is due to the relatively late introduction of the term «брюки» 'trousers'. In the 18th century during the period of Peter the Great's reforms, it meant «sailor's pants» (hence the derivative word in naval terminology «брюканец» [brukanets] 'mast shin pad' later appears (i.e., «брюки» 'trousers', entering the usus, become a productive model). In the 19th century trousers were 
actually an indicator of the social status of a man, and apart from the courtiers, they were also worn by representatives of the highest aristocracy. For this reason, according to the law of tradition, the transformation of pants into trousers was slow; however, the Russian language today allows both variants in colloquial speech and the variant «брюки» 'trousers' is used as a description of any model of the lower part of clothing in written speech. Nowadays, both names are used outside the context of the gender of the person who wears these clothes.

An interesting example within the framework of this topic is the common name for a woman's dress - сарафан [sarafan] 'pinafore dress', which comes from the Persian sarāpā or sarāpāi «dressed from head to toe» — a direct borrowing from the Turkic languages with the same lexical meaning. In modern dictionaries and in the everyday sense, we meet the interpretation of «a women's dress without sleeves for the spring-summer period, which is worn on top of a sweater jacket or independently» [5. P. 686]. For a long time, from the end of the 19th to the end of the 20 th century, the name «сарафан» 'pinafore dress' almost completely replaced платье [plat'ye] 'dress' and its derivatives. And in the beginning of the 21 st century a pinafore dress as a type of sleeveless dress became widespread, and even a special type of cropped dress was released, which was named «бэби-долл» (after the name of the cut) from English baby-doll — «doll dress».

A similar derivation of the meaning can be observed in the lexeme «бахильл» [bakhily] 'shoe covers'. Etymologically — «boots with high tops» [13]. Initially, in Russia, peasants called any shoes that were intended only for work, but were unsuitable for walking shoe covers. According to Mikkola [14. P. 82], the lexeme is borrowed from the Middle Latin bacle - «women's shoes», which he compares with the Greek $\beta \alpha \kappa v i \delta \varepsilon \varsigma^{\circ} \varepsilon \tilde{i} \delta o \varsigma$ vi $\pi \delta \delta \eta \mu \alpha \tau \omega v$ [7. P. 136]. Today this word is synonymous to «бродни» [bodni] 'wading boots', «болотники» [bolotniki] 'waterproof boots' — «soft rubber (formerly leather, yuft from a single piece) boots with very long tops that cover the thighs; designed for walking in swamps, water; used by fishermen and hunters. A more common meaning in everyday life is «special protective covers or stockings worn over shoes indoors for sanitary and hygienic purposes» [15].

Similar changes are observed in the transformation of the meaning of the lexeme «балахон» [balakhon] 'hoody'. By origin, балахон 'hoody' is a Turkic word that came into the Russian language at the beginning of the 17 th century, meaning «a kind of peasant's caftan». Later, its interpretation added the following meaning — «the type of loose overcoat of straight cut» [13. P. 86]. This Turcism was especially widespread dialectally, where many new forms and meanings of the word are known: балахонец [balakhonets] and балахонщик [balakhonshchik] 'hoodies' master and trader', балахонники [balakhonniki] 'monks', балахонина [balakhonina] 'woolen, thin and rare fabric for hoodies', балахонник [balakhonnik] 'poor man, beggar', балахончик [balakhonchik] 'women's sweater jacket', балахоня [balakhonya] 'loose outer garment' and 'a man in long and wide clothes', балахонский [balakhonskiy] 'monastic', балахонничать [balakhonnichat'] 'to be 
engaged in sewing hoodies'. In its modern meaning, the word does not carry a negative or demeaning emotional and expressive connotation. On the contrary, this type of clothing is popular among young people adherent to hip-hop and rap subcultures.

Among the original names of the wardrobe, it is worth noting the appearance of such warm outwear as душегрея [dushegreya] 'women's warm sleeveless jacket'. The modern name is душегрейка [dushegreyka] 'women's warm sleeveless jacket' (outdated душегрея; in the 12th century after the fall of the reduced sounds and the loss of the final $-<\mathbf{u}>$ in verbs with a vowel stem in the imperative mood «грей» instead of «греи» + suf. $-\mathbf{\kappa})$ was preserved in dialects with the same meaning - «women's warm jacket, usually sleeveless, with gathers at the waist» [5. P. 179]. At the end of the 18th century this word was replaced by the identical «телогрейка» [telogreyka] 'quilted jacket', which was associated with the weakening of the role of the church and the corresponding spiritual teachings, when the change in state ideology led to a change in the language paradigm. In this regard, at about the same time, such a kind of warm jacket as a ватник (coll.) [vatnik] 'winter cotton-padded jacket' or a wadded jacket' appears. This concept appeared among the soldiers of the Russian army during the Russian-Turkish war of 18771878. Order of the Military Department № 199 for 1885 offered the Cossack a choice to have a sheepskin coat or a wadded beshmet. Short fur coats were much more practical, and were obligatory in the army until 1900. However, sheepskin coats did not fit into the pack, and from 1901 the Cossacks were obliged to have wadded jackets [16. P. 27].

Special gender distinctions in the meanings of words are found in the names of accessories. The word «чепчик» [chepchik] 'bonnet' comes from чеnец [chepets] (proto-Slavic * čepscb related to Lithuanian kepùrè — «cap») — «a female headwear, which is a knitted or sewn cover that hides hair, may have ties under the chin» [7. P. 333]. Until the 17th century it was the item of summer women's and children's wardrobe, and then, until the end of the 19th century, the bonnet was a household headdress for women. It had the shape of a soft bonnet, decorated with ruffle, ribbons, lace and artificial flowers. Currently, this accessory and its corresponding name are used only to designate a headdress made of onelayer, usually cotton, fabric for newborns.

A number of names for a headdress, which was originally worn only by men, are the words сомбреро [sombrero] 'sombrero', эспаньерка [espanierka] 'foreand-aft cap', ичлиндр [tsilindr] 'top hat'. Сомбреро 'sombrero' is a «national Mexican hat with large brims» [17], эспаньерки 'fore-and-aft caps' are «envelope сарs», ичилиндр 'top hat' comes from German Zilinder (Latin cylindrus, dating back to the Greek kylindros). These lexemes are similar in that they can currently be part of the female image.

The described names have been used for a long time: from the moment of borrowing to the present day. Today, most of them have broader semantics than when they were borrowed. It should be noted that the linguistic tradition of the 
fashion sphere tends to deductiveness, that is, the selection and use of a number of private onyms instead of a more general one. Thus, instead of a general шляпа 'hat' or брюки 'trousers', such borrowings as бейсболка 'baseball cap', рэперка 'rapper сар', кепка 'сар', бандана 'bandanna', панама 'bucket hat' or джогzерь 'joggers', карго 'cargo pants', палацицо 'palazzo pants', кюлотьл 'culottes', etc. are included in the usus.

At the same time, the above examples indicate that over time, a word can change not only gender and age. These changes are due to historical phenomena, social norms, they are gradually recorded in dictionaries and encyclopedias. The listed names of clothes and their meanings demonstrate the gender division of society, which, as we approach the present day, is leveled. J. Entwistle notes that modern fashion styles are becoming more androgynous due to extralinguistic factors: a change in the political and ideological system, a change in gender roles, emancipation [6. P. 241]. Undoubtedly, all these phenomena are reflected in the language.

\section{Names of Clothing Items and their Phonetic and Grammatical Assimilation}

Since the 21 st century fashion industry has given rise to more and more diverse styles and models of the same type of clothing, which explains the need for their nominative distinction. This contributes to a significant influx of foreign-language lexemes into the Russian language and the rapid rate of their assimilation, but at the same time leads to a serious grammatical adaptation of new units: «doubling» of the plural form, unusual patterns of stem concatenation, phonological inconsistencies, etc.

\section{Phonetic Assimilation of Borrowed Names of Fashion Items}

A fairly common way of assimilating foreign lexical units in the Russian language is their phonetic adaptation. Many names for clothing and accessories came to Russia from the Anglo-American fashion tradition, so their name in Russian begins to be pronounced either in accordance with the articulatory characteristics of the source language, or in accordance with the laws of the recipient language.

For example, the name of trousers брюки-бэгzи (багги) [bryuki-beggi] 'baggy trousers' from English bag — «bag» + adjective suffix $-\mathbf{y}-$ baggy. A feature of the pronunciation of this term is the stressed sound $\Lambda / æ$ in the first syllable багги/бэгги ['bagi] / ['bægi]. The phonetic position of the first vowel in American English in the word baggy is weak, so different pronunciation options may have a normalized (['bægi]) or dialectal African American territorial pronunciation (['bagi]); in some cases we find ['bıgi]. The latter two cases observe the pronunciation of the phoneme [æ], typical of the African American population living in the western states and following a special style in music and lifestyle 
(underground). This explains the fluctuations in the pronunciation of the vowel sound in the first syllable in Russian as the recipient language.

Thus, the process of borrowing lexemes denoting the names of clothes, common in the American subculture, still presupposes variability in the pronunciation of individual lexical units due to the psychological need of Russian-speaking followers of this culture to convey the authenticity and originality of sounds in the borrowed words. Similar phonetic fluctuations are found in the nomination of subjects such as durag [durag/duræg], snapback [snæpbek/snæpbæk], etc.

\section{«Doubling» of Plural Forms of Nouns Denoting Items of Clothing}

«Doubling» of the plural is one of the most characteristic features of the grammatical assimilation of lexical borrowings in Russian environment. It is expressed in the fact that the word in the source language has the label «plural». However, the recipient language considers such a word as the basis for further affixation. Therefore, in the process of the entry of a foreign non-declining plural noun into the Russian language, it loses its original morphemic seams and acquires the plural ending of the recipient language in accordance with its grammatical laws. As a result, the word is no longer felt by Russian speakers as foreign. The most common examples of words in which the number is «doubled» are the names of various types of trousers, since, by analogy with the words «брюки» 'trousers', «штаны» 'pants', the borrowed word form acquires a plural ending.

The name чиносы 'chinos' came into Russian from the American version of the English language, where chinos (pl.) comes from China + plural suffix -s, added by analogy with common jeans, trousers, pants that do not have a singular form. This type of trousers appeared in the 19th century as part of the uniform of the American army and got its name from the cotton imported from China from which these trousers were sewn. It is worth noting that this is an example of a kind of grammatical pleonasm. In the English language chinos is labeled «plural», in Russian, the calque «чинос» 'chinos' acquires a common plural ending, _<ы>. A similar process of grammatical assimilation of borrowing can be seen in the words джинсы 'jeans', броги 'brogues', брюки 'trousers, pants'. In modern Russian colloquial speech and the Internet space, both variants of the name чинос/чиносы 'chinos' are used; in written sources, for example, in the media and clothing catalogues, only the name «чинос» 'chinos' is acceptable. This lexeme has no grammatical paradigm, it does not change in cases and number.

Another striking example of «doubling» the inflection of the plural number is слаксыл 'slacks'. Despite a certain similarity in functionality and lexical content of the terms слаксы 'slacks' and чинос 'chinos', the linguistic characteristics of these terms still have some differences. The main difference is that there is no invariant for the name «слаксы» 'slacks'. In this case, English calque slacks, by analogy with чинос 'chinos', will not be an example of variability, since the name came to spoken language and the Internet in the plural, adapted to the rules for the formation of the 
plural in Russian, i.e. with the ending $-<_{\mathrm{b}}>$ and, accordingly, with the full declension paradigm. In the articles of fashion magazines we can find case forms: «обладатель слаксов» 'slacks owner', «преимущество перед слаксами» 'advantage over slacks' and so on. However, due to the similarity of the context of the use of chinos and slacks in more official sources, the second name will more often be replaced by the first or another, more neutral synonym, since the name «слаксы» 'slacks', which does not allow a tracing invariant, has rather a colloquial functional-style colouring.

The model of trousers [kyuloty] кюлоты 'culottes' has similar grammatical features. However, this type of clothing has a number of additional characteristics, both intraword and extralinguistic. Кюлоть 'culottes' are «short pants fastened under the knee, in the past were part of the aristocratic wardrobe. Culottes were worn with stockings and shoes with buckles» [15]. In their modern form, culottes differ not only in style, but also in gender. This type of trousers is characterized by a special straight, flared cut to the bottom, which makes them look like a skirt (in colloquial speech, the equivalent of a trouser-skirt is acceptable), therefore culottes are considered women's outfit.

The borrowing nature of the modern name of these trousers suggests that the revival of this term was facilitated by the English language, in which culottes are taken directly from French by direct borrowing. Just like the English culottes, the Russian word «кюлотьл» has a grammatical characteristic of plural number, however, given the relative popularity of the term since the 18th century, the plural ending $-<_{\mathbf{b}}>$ is attached directly to the stem, but not to the whole word form (as in the words джинсы 'jeans', слаксы 'slacks', etc.). Thus, the English version is an intermediary between the original French culotte (singular), which goes back to the French culot — «the lower part of any clothes» [18]; and Russian «кюлоты » (plural). The penetration of this lexeme into the English language in the plural can be explained by two processes. The first is associated with the use of this word in the composition of phraseological units and set expressions. The most popular of them in Western Europe in the 18th century was a combination of «sans-culottes» ('without culottes', 'without a pair of pants'), which meant «the lower strata of the population who wore working clothes, but not breeches - a symbol of the aristocracy of that time» [19. P. 2-3]. The second process is the assimilation of new words under the law of analogy. Then, English culottes $>$ French stem culotte + plural suffix $-\mathbf{s}$ was subjected to grammatical development by analogy with pants, trousers, etc.

\section{Weak or Partial Assimilation of Grammatical Borrowings in the Names of Fashion Items}

Due to the increase in the variety of clothing models, the language is enriched with borrowed vocabulary, which, however, is not always fully mastered. The examples below show the most frequent linguistic features of borrowing, which are 
manifested in the specifics of word formation. As a rule, these denotations are included in the usus and are mastered in the case of frequent use in fashion magazines and on sites dedicated to clothing. For example, if a style comes into fashion, it is widely described.

The prototype of пуловер [pullover] 'pullover' is a knitted sweater worn by Scottish and Irish sailors in the 19th century when they went to sea. Sailors and fishermen's wives knitted comfortable sweaters that were worn over undershirts. Due to the lack of a fastener, the predecessors of pullovers warmed the body better, protected it from the wind. Modern pullover models appeared in the 1980s in England. They were worn by tennis and golf players who called them «buttonless jackets». The absence of fasteners and the narrow fit provided the athletes with comfort during the competition. Following the athletes, the pullover entered the wardrobe of their fans, and then the mass consumer. The lexico-semantic way of this term's borrowing presupposes the fusion of the elements of the former phrase: «риll over» transforms into «пуловер» 'pullover'. In the source language, the phrase consists of a combination of a verb and a particle. Since the phrasal verb in the English language is an integral semantic unit, the process of the unit's transition to the Russian language, in which there are no similar grammatical formations, proceeded according to the type of conversion. In the recipient language, «пуловер» 'pullover' is characterized as a masculine noun, singular. This form is determined by zero inflection after the consonant by analogy with common nouns of this type: дом 'house', стол 'table', стул 'chair'. At the same time, there is a transition of stress, which in the English version falls on the first syllable of the second component of the phrase over, in Russian - either on the second syllable of the unit or on the last. Fluctuations of stress can be associated both with the ongoing process of the unit acquisition in Russian, and with a number of internal reasons: rhythmic convenience, physiology of respiration, articulation data, and others.

Despite the fact that most fashion terms come from American English, the word джемпер [dzhemper] 'jumper' came from British English through direct borrowing and, unlike many similar names, has acquired a declension paradigm (case, number). In the terminology of world fashion, the British version of the name of this product is considered almost dialectal, and international fashion publishers use Americanisms: raglan sleeve sweater («sweater jacket with raglan sleeves»), grandpa sweater («grandfather's sweater»), half-zip sweater («zipped collar sweater jacket»), crew neck sweater («sweater jacket with a round neck»), set-in sleeve sweater («sweater jacket with visible seams on the sleeves in the shoulder area»), mock turtleneck sweater («sweater jacket with a high collar that fits the neck»), which allows differentiating different models. However, in Russian, «Джемпер» [dzhemper] 'jumper' is the exact lexical analogue of the English word, as it reproduces the association of British people who believe that cвumep [sviter] 'sweater' is «a product made of denser materials that is used exclusively in cold weather» [20. P. 1473], and джемпер [dzhemper] 'jumper' is a «light» version of a sweater for daily wear over a shirt, blouse, or other kind of garment with a collar, which are not customary to be worn separately [21]. 
Most English-speaking etymologists and compilers of explanatory dictionaries consider jumper to be a hyponym of the word свитер 'sweater' and a hyperonym of semantically similar words пуловер 'pullover' and кардиган 'cardigan', that is, they are cohypontms of the word джемпер 'jumper'.

Another interesting example is the term жакет 'jacket'. It derives from the Middle French noun jaquette, which meant «small or light tunic», but the modern meaning differs from this definition. Until the 2000s, pea-jacket and jacket were attributes of men's and women's wardrobes, respectively; later, in order to save speech efforts, the first option was abolished. Due to the increased propaganda of fashion without pronounced gender characteristics, the tendency to differentiate gender disappeared, and only the name jacket of broad semantics remained in English-speaking countries. It is used in the general sense of «men's/women's jacket» [20. P. 769], «coatee», «coat» or with an additional element bomber jacket («bomber»), down jacket («puffer jacket»), bed jacket («top of pajamas») to denote a wide range of these clothes' models.

In Russian, the words пиджак [pidzhak] 'jacket' and жакет [zhaket] 'ladies' jacket' are not perceived as one root. The word пиджак 'jacket' has existed in Russian for quite a long time, therefore it has a high degree of assimilation: phonetic and graphic, and is not associated with the original pea-jacket. In addition, these words designate items of clothing intended for people of different genders: a пиджак 'jacket' - for men, and жакет 'ladies' jacket' — for women.

In English, the word jacket is the main, generic component for many types of outwear. For example, бомбер [bomber] 'bomber jacket', a type of jacket designed for the US Air Force pilots during World War II, evolved from the combination flight jacket «pilots' coat», which later became bomber jacket, as it was worn by heavy bomber pilots. Over time, the colloquial short name bomber was stuck behind a jacket of this cut, but in written speech only bomber jacket is possible. This example illustrates the process of simplifying the name in the recipient language by cutting off one of its components.

However, the simplification of the lexical unit when borrowing may not occur. Thus, the concept kpon mon 'crop top' came to the Russian language as a composite unit. It is noteworthy that in English, crop top and its derivatives denote any kind of cropped upper part of clothing, adding, depending on the style, other components to the general name (tummy top, midriff-baring top), while the Russian language for designating a sweater without sleeves uses «mon» 'top' or colloquial «майка» 'sleeveless undershirt', and «кроп-топ» 'crop-top' is defined as «any sweater with a shortened cut (to the waist line), regardless of the length of the sleeves» [22].

The gender of borrowings needs a separate discussion. Thus, for example, in the word $x y \partial u$ [hudi] 'hoody', we find fluctuations between the signs of the neuter (as a general rule, like пальто 'coat', кепи 'сар') and the feminine gender (by analogy with the word толстовка 'sweatshirt'). This feature is observed in a large number of lexemes borrowed from the English language, since in English the gender of nouns is determined by the context; outside the context, most inanimate nouns are classified 
as indeterminate gender (indefinite/undefined gender). In the Russian language, nondeclining nouns of foreign origin, denoting inanimate objects, most often refer to the neuter gender (for example, такси 'taxi', кашне 'muffler'). Худи 'hoody' is a word of foreign origin, non-declining and inanimate, that is, in full accordance with the specified rule, it can be considered a neuter noun (удобное, красивое худи 'comfortable, beautiful hoody'). On the other hand, there is a rule according to which the grammatical gender is determined by the generic concept of a word, therefore, худи 'hoodie', like its generic concept толстовка 'sweatshirt', can be agreed in the feminine gender. However, many Russian speakers use the word $x y \partial u$ 'hoody' as masculine, which can be explained by a psycholinguistic analogy with the most common word for the masculine свитиот 'sweatshirt', the models of which differ from the hoody only by the absence of the hood.

It is worth noting that a large number of the outwear names of the of men's and women's wardrobe (sweatshirt, longsleeve, polo, sweater, body, cardigan, jodhpur) popular among Russian fashionmongers, are examples of a calque and represent a direct transfer of the original name to the recipient language, which causes indeclinability of the majority of them.

Thus, the majority of modern borrowings in the field of fashion have a rather low degree of assimilation in the language owing to their infrequent, professional use in comparison with denotations of wider semantics. The rate of assimilation of a lexical unit in a language is significantly influenced by the factor of the product's «trend» in the season, which determines how tightly borrowing will enter the usage of the speakers of the given language.

\section{Hyper-Hyponymy of Borrowings Denoting Accessories}

Borrowing process of names for handbags and jewellery differs from the process of adopting names for other fashion items in their constant variability. Unlike styles of clothing, fabrics, types of shoes, fashion for handbags, glasses and jewellery changes every season, which is due to the interest of designers in this category of accessories and their desire to create new trends. Therefore, some names of bags, jewellery and glasses, which have no analogues, are fixed in the language (несессер 'toiletry case', борсетка 'man bag', шопnер 'shopper bag', чокер 'chocker', снуд 'snood', etc.), while others are borrowed for a short period of time, which causes a low degree of their assimilation.

In general, this category of fashionable goods is interesting in the way that it more often than for other field concepts preserves the original sound and the presence of the generic name in the beginning and in the end of the compound lexical unit. So, using the example of lexemes, шапка-бини 'beanie hat', шарф-снуд 'snood scarf', очки-вайфареры 'wayfarer glasses', серьги-кролеры/клаймберы 'crawler/climber earrings', both tendencies can be distinguished. First, in all these words there is a practical transcription of the original word forms, i.e., a clear graphic and phonetic imitation of the word of the source language. Secondly, they demonstrate the 
presence of a Russified part («шапка» 'hat', «очки» 'glasses', «серьги» 'earrings'), which serves as a clarifying component, since in the recipient language the hyponymic component is perceived outside the context as an alien element that requires explanation. The declension paradigm in such words is observed only in the generic concept expressed by the Russian lexical unit.

\section{Conclusion}

The study showed that modern terms for clothing and accessories borrowed in modern Russian most often come from American and British variants of the English language, and also from Italian and French. In their lexical meaning and phonetic image, they bring cultural labels of their country of origin to foreign consumers. At first they are perceived as alien, but steadily they become a part of the life of a Russian person, and the language itself gradually begins to «grind» them according to its internal rules.

In foreign clothing names borrowed into the Russian language, there is currently a tendency to use a foreign hyponym as an analytical adjective, which indicates a transitional stage in the assimilation of the word by the language; at the same time, it helps a consumer who does not speak foreign languages to navigate when choosing the necessary product and not to get confused while reading a text in a fashion magazine. Nevertheless, many clothing and accessories names remain unchanged for the time being, they are transferred to Russian in the form of direct transliteration or calque, thereby demonstrating a rather weak degree of their prevalence among the mass buyer.

However, despite the tendency emerged in recent decades towards maintaining the purity of the Russian language, protecting it from unwanted and unnecessary foreign words, and preserving the strength of the language tradition, the process of lexical borrowing continues. It is supported by the texts in world fashion periodicals, speeches of fashion designers and fashion historians, the Internet space of fashion. This inevitably leads to the assimilation of the most common terms among Russian native speakers.

\section{Библиографический список}

1. Лунькова Л.Н., Букина Л.М. Семантические англицизмы французского интернет-форума // Вестник Российского университета дружбы народов. Серия: Теория языка. Семиотика. Семантика. 2020. Т. 11. № 1. С. 92-101. doi:10.22363/2313-2299-2020-11-1-92-101.

2. Перфильева Н.В., Ху Пэйпэй. Словообразовательные модели неологизмов-заимствований в русском и китайском языках // Вестник Российского университета дружбы народов. Серия: Теория языка. Семиотика. Семантика. 2012. № 2(4). С. 69-75.

3. Крылов Г.А. Этимологический словарь русского языка. СПб: ООО «Виктория плюс», 2004.

4. Ушаков Д.Н. Толковый словарь русского языка. М.: Гос. ин-т «Сов. энцикл.»; ОГИЗ; Гос. изд-во иностр. и нац. слов., 1935-1940.

5. Ожегов С.И., Шведова Н.Ю. Толковый словарь русского языка: 80000 слов и фразеологических выражений. М.: АЗЬ, 1995. 
6. Энтуисл Дж. Модное тело. М.: Новое литературное обозрение, 2019.

7. Фасмер М. Этимологический словарь русского языка: В 4-х т.: Пер. с нем. О.Н. Трубачёв. М.: Астрель-АСТ, 2004.

8. Berneker E. Slavisches etymologisches Wörterbuch. Heidelberg, 1908-1913.

9. Ефремова Т.Ф. Новый словарь русского языка. Толково-словообразовательный. М.: Русский язык, 2000.

10. Шанский Н.М. Этимологический словарь русского языка. М.: Изд-во МГУ, 1965.

11. Тишков B.A. Народы и религии мира. М.: Большая Российская энциклопедия, 1998.

12. Даль В.И. Толковый словарь живаго великорускаго языка. М.: Издание Общ-ва любителей российской словесности, 1994.

13. Большой толковый словарь русского языка: А-Я / РАН. Ин-т лингв. исслед.; Сост., гл. ред. С.А. Кузнецов. СПб.: Норинт, 1998.

14. Hesychii Alexandrini Lexicon, hrsg. von Kurt Latte. A- $-\Delta$. Kopenhagen, 1953.

15. Энциклопедия моды и одежды. EdwART. 2011. Режим доступа: https://rus-fashiondict.slovaronline.com/ (дата обращения: 27.06.2020).

16. Фролов Б.Е. Материалы к «Военному лексикону кубанских казаков» // Дикаревские чтения: материалы Региональной науч. конф., Краснодар, 10-13 окт. 2003 г. / сост., науч. ред. М.В. Семенцов. Краснодар: Крайбибколлектор, 2003.

17. Национальный корпус русского языка. Режим доступа: ruscorpora.ru. (дата обращения: 20.07.2020).

18. Calasibetta C.M., Tortora P. The Fairchild Dictionary of Fashion. NY: Fairchild Books, 2010.

19. Soboul A. The Sans-Culottes: The Popular Movement and Revolutionary Government, 1793-1794. New York: Doubleday, 1972. pp. 2-3.

20. Cambridge Advanced Learner's Dictionary. Cambridge: Cambridge University Press, 2008.

21. Толковый online-словарь: Collins Online English Dictionary. Режим доступа: https://www.collinsdictionary.com/dictionary/english (дата обращения: 27.06.2020).

22. Толковый online-словарь: Wiktionary. Режим доступа: https://ru.wiktionary.org/wiki/ $\% \mathrm{D} 0 \% \mathrm{BA} \% \mathrm{D} 1 \% 80 \% \mathrm{D} 0 \% \mathrm{BE} \% \mathrm{D} 0 \% \mathrm{BF}-\% \mathrm{D} 1 \% 82 \% \mathrm{D} 0 \% \mathrm{BE} \% \mathrm{D} 0 \% \mathrm{BF}$ (дата обращения: 27.06.2020).

\section{References}

1. Lunkova, L.N. \& Bukina, L.M. (2020). Semantic Anglicisms in French Internet Forum. RUDN Journal of Language Studies, Semiotics and Semantics, 11(1), 92-101. doi:10.22363/23132299-2020-11-1-92-101. (In Russ.).

2. Perfilieva, N.V. \& Hu, Peipei (2012). Word-building Patterns in Neologisms-Loanwords in Russian and Chinese. RUDN Journal of Language Studies, Semiotics and Semantics, 3(4), 69—75. (In Russ.)

3. Krylov, G.A. (2004). Etymological dictionary of the Russian language. St. Petersburg. (In Russ.).

4. Ushakov, D.N. (1935-1940). Explanatory dictionary of the Russian language: Vol. 1. Moscow. (In Russ.).

5. Ozhegov, S.I. \& Shvedova, N.Yu. (1995). Explanatory dictionary of the Russian language: 80,000 words and phraseological expressions. Moscow. (In Russ.).

6. Enthusl, J. (2019). Fashionable body. Moscow: New Literary Review. (In Russ.).

7. Vasmer, M. (2004). Etymological dictionary of the Russian language in 4 volumes, O.N. Trubachev (Tr., ed.). Moscow: Astrel-AST. (In Russ.).

8. Berneker, E. (1908-1913). Slavisches etymologisches Wörterbuch. Heidelberg. (In Germ.).

9. Efremova, T.F. (2000). New dictionary of the Russian language. Explanatory and derivational. Moscow: Russian language. (In Russ.).

10. Shansky, N.M. (1965). Etymological dictionary of the Russian language. Moscow: Publishing house of Moscow State University. (In Russ.).

11. Tishkov, V.A. (1998). Nations and religions of the world. Moscow: Great Russian Encyclopedia. (In Russ.). 
12. Dal, V.I. (1994). A dictionary of the living Russian language (in 4 vol.). Moscow: Terra. (In Russ.).

13. The Big Explanatory Dictionary of the Russian Language: A-Ya (1998). St. Petersburg: Norint. (In Russ.).

14. Hesychii Alexandrini Lexicon (1953). hrsg. von Kurt Latte. A $-\Delta$. Kopenhagen.

15. Encyclopedia of fashion and clothing. EdwART. (2011). URL: https://rus-fashiondict.slovaronline.com/ (accessed: 27.06.2020).

16. Frolov, B.Ye. (2003). Materials for the "Military lexicon of the Kuban Cossacks" In Dikarevskie readings: materials of the Regional scientific conference, Krasnodar, 10-13 October, 2003, M.V. Sementsov (ed.). Krasnodar: Kribibkollector.

17. National corpus of the Russian language. URL: ruscorpora.ru (accessed: 20.07.2020).

18. Calasibetta, C.M. \& Tortora, P. (2010). The Fairchild Dictionary of Fashion. NY: Fairchild Books.

19. Cambridge Advanced Learner's Dictionary (2008). Cambridge: Cambridge University Press.

20. Soboul, A. (1972). The Sans-Culottes: The Popular Movement and Revolutionary Government, 1793-1794. New York: Doubleday. pp. 2-3.

21. Explanatory online dictionary: Collins Online English Dictionary. URL: https://www.collinsdictionary.com/dictionary/english (accessed: 27.06.2020).

22. Explanatory online dictionary: Wiktionary. URL: https://ru.wiktionary.org/wiki/\%D0\%BA\% D1\%80\%D0\%BE\%D0\%BF-\%D1\%82\%D0\%BE\%D0\%BF (accessed: 27.06.2020).

\section{Сведения об авторе:}

Недопекина Екатерина Михайловна, кандидат филологических наук, доцент кафедры общего и русского языкознания Российского университета дружбы народов; научные интересы: семантика, прагматика; e-mail: nedopekina_em@rudn.ru.

\section{Information about the author:}

Ekaterina M. Nedopekina, PhD in Philology, Associate Professor of General and Russian Linguistics Department, RUDN University; academic interests: semantics, pragmatics, discourse analysis; e-mail: nedopekina_em@rudn.ru. 